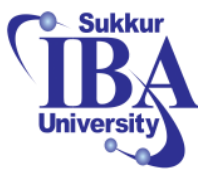

Vol. 2, No. 2 | July - December 2019

\title{
Techno-Economic Analysis of Solar Thermal Water Heaters in Pakistan
}

\author{
Muhammad Aitezaz Hussain ${ }^{1}$, Mudasar Rashid ${ }^{1}$, Sobab Khan ${ }^{1}$ and Ahtesham Rahim ${ }^{1}$
}

\begin{abstract}
:
Pakistan is in shortage of power due to gap in its supply and demand of energy. Country's energy and power sectors mainly depend upon the crude oil and fossil fuels in which natural gas is main source of energy in the domestic and commercial zones, yet due to the poor management and undiscovered reservoirs the demand of gas is also high and situation in the winter gets worse when the demand reaches to its peak. In contrast, Pakistan industrial sector uses daily thousands of gallons of hot waters for its different processes and hot water mainly heated through conventional sources of energy. In this paper a sustainable and alternative approach has been adopted for these issues, the study has shown that the solar thermal energy can play a significant role in the Pakistan's geography. A newly introduced technology discussed is Solar Thermal water heaters. The analytical analysis has been carried out to compare conventional heaters (gas) with the solar water heaters. The cost analysis, energy saving, payback period was found by the mathematical approach.
\end{abstract}

Keywords: Sustainable, Solar thermal Water heaters, fossil fuels, climate

\section{Introduction}

In today's life, first and important entity to live life with peace is the availability of the energy to humans in every aspect. Energy plays an important role in Socioeconomic development of a country [1].The prime source of the energy on surface of earth is the natural resources of the world, that are facing the major problems such as depletion with time due to which its price is increasing day by day and most importantly they are bringing the climate changes in the environment very rapidly [2]. So taking into the account these issues it is highly recommended by the researchers to switch towards the sustainable and environmental friendly and most importantly affordable sources of energy for fulfilling the energy needs [3]. From the last few years Pakistan is also facing a severe energy shortage. This problem hugely effected the daily routine and most importantly the economy of the country. The shortfall is around 5000 to $6000 \mathrm{MW}$ due to which the rural areas are going through 12 to 16 hours of load shedding while the urban areas are under 8 to 10 hour of electricity cutoff in summer and in winters the cities suffers 4 to 6 hours while villages bear 6 to 9 hours of load shedding $[4,5]$. And if serious

\footnotetext{
${ }^{1}$ Department of Renewable Energy Engineering US. Pakistan Center for advanced Study in Energy, UET Peshawar

Corresponding Author: aitizazk36@gmail.com
} 
initiatives on immediate bases aren't taken this shortfall can increase in the upcoming years. Fig. 1 shows the gap in supply and demand of electricity [6]. In this regard Pakistan government has taken some serious steps to reduce the burden on conventional sources and introduce cheap sources by considering alternative means of energy like wind, hydro, solar PV and solar thermal energy due to its clean feathers $[1,7,8]$.

Potential of renewable energy in Pakistan in very phenomenal due to its unique climate. Pakistan lies mostly on sunny track so it receives the humongous amount of solar radiations annually shown in Fig.3. Solar energy is hugely spread and available in large amount throughout the country [2, 5]. On average Pakistan receives 4.45 to 5.83 $\mathrm{kWh} / \mathrm{m}^{2} /$ day of the global radiation. Even this minimum value of the average radiations 4.45 $\mathrm{kWh} / \mathrm{m}^{2} /$ day is quite higher than the world average radiation which is $3.61 \mathrm{kWh} / \mathrm{m}^{2} /$ day. So it shows that Pakistan can get enough benefits of the solar energy and can fulfill lot of its energy needs using this free available technology. The recording of sunshine in different parts of the country is being carried out by the isolation stations installed in big cities like Lahore, Karachi, Peshawar, Islamabad Multan and Quetta. Fig. 2 Shows Direct normal solar radiation for summer in Pakistan [9] . Pakistan has taken some good steps towards the harnessing the renewable energies source after the 2006 renewable energy policy. Some wind and solar power plants were started. Feasibility reports were studied. Fig. 2 shows the solar irradiance of the country which can be used for harnessing the solar energy at high level.

In Pakistan idea of solar thermal water heaters has been introduced for the first time on commercial scales at one of the leather Industry located in Lahore. The solar collectors were evacuated tubes collector type used $400 \mathrm{~m}^{2}$ areas. The whole arrangement gives hot water up to 70 to $80^{\circ} \mathrm{C}$ with $10^{\circ} \mathrm{C}$ change to the inlet water. After the cost analysis it has been found out that the system has saved the cost of fuel up to $33 \%$ annually.
Thus, after few years the setup was updated and extended. It means we can use it for our domestic Scale too. And it can give us 60 to $70 \%$ saving annually [5]. This technology is very beneficial, cost effective, and clean and needs very negligible maintenance. But due to its high capital cost as compared to the conventional heaters yet this technology isn't fully developed [3, 4]. However, it is one of the most efficient technology and can be the best solution for the areas where natural gas isn't available or deficient. Also to the already decreasing natural resources and shortage of the power it is the best alternative [2].

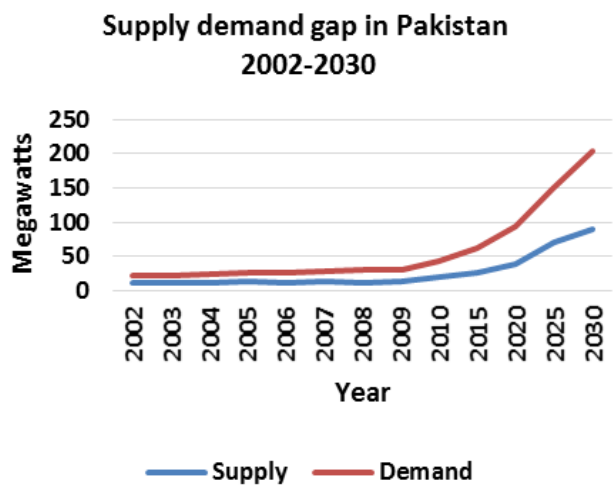

Fig. 1. Forecast of demand and supply gap

\section{Litreture Study}

\subsection{History}

The history of usage of solar heaters is very old. An inventor name Clarence Kemp in 1886 made a tank enclosed it in wooden box which was first commercial type solar water heater [10], these heaters are still used and are called Integral collector storage type heaters. The Solar water heating technology was gradually growing and in 1920 the flat plate solar waters heaters were introducing in Florida and south California, and were prominently used in America till 1960. After 1960, the market of solar thermal water heaters came into the Asia and Japan adopted this technology first. After 1973 energy crisis the technology grew abruptly. 
The developed countries like America, Japan, India, Canada Australia, Portugal, Spain and United Kingdom's widely opened their market to this technology. Spain became the $1^{\text {st }}$ country which used the solar photovoltaics and $2^{\text {nd }}$ country for solar thermal water heating technology in 2005 and 2006 respectively [11].The technology is now also very

Fig. 2. Solar irradiations for different cities of Pakistan, $(\mathrm{MJ} / \mathrm{m} 2)$

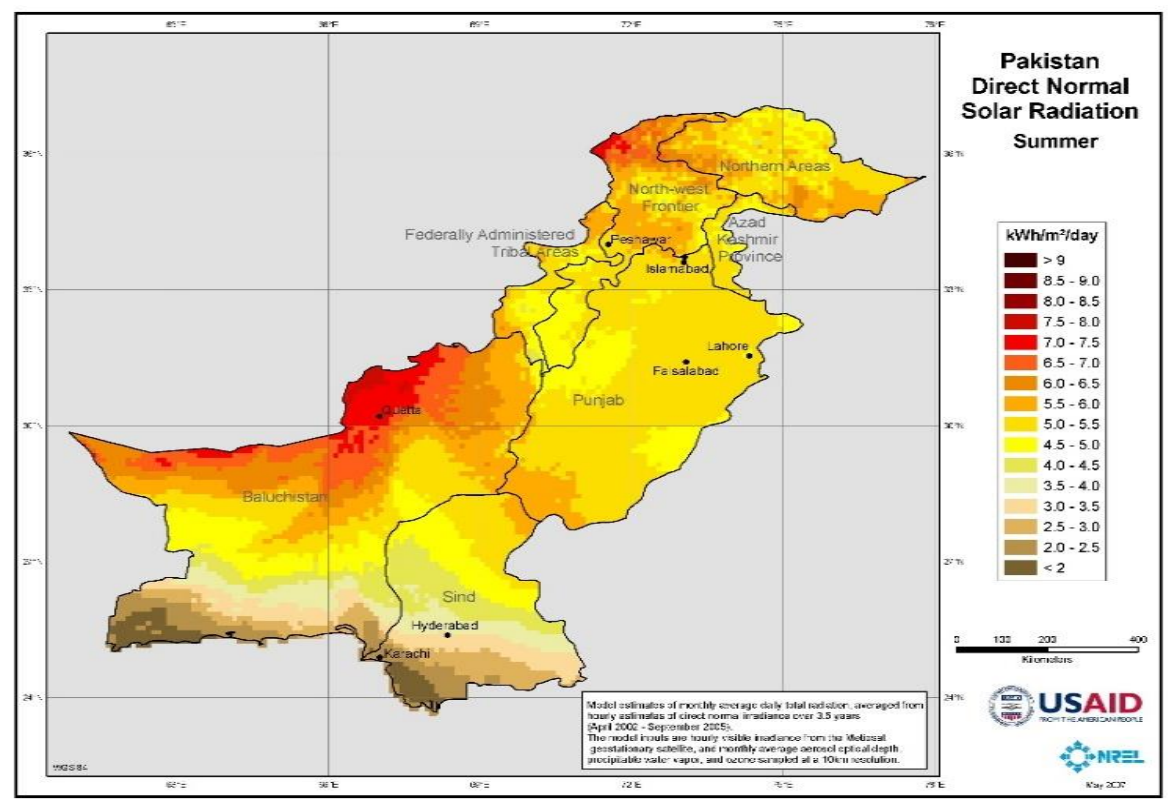

Fig. 3. Direct Solar Irradiance for different regions of Pakistan

In china around 30 million household uses solar water heaters due to the advanced 
evacuated tube collectors properties that enables it be used in cloudy sky or in cold climate with freezing temperature [12].

\subsection{Solar collectors}

Something that can transform solar energy into the heat is supposed to be the solar thermal collectors. Like the earth in self and the human body are also the clear examples of solar collectors. In more technical definition, the solar collector which helps to convert the incoming radiations of sun into useful form of heat and the example is warm air or water or any fluid. This principal can be simply realized by the hose pipe used to convey water for it and is also example of the simple unglazed collector. While minimizing heat loss from the system we used the glazed type solar collectors such as flat plat or evacuated tube collectors. The system can be further improved by using the concentrated collector with mirror which focuses the sun more on the collectors. The temperature up to $3500^{\circ} \mathrm{C}$ could be achieved in such method and the type is called solar furnace [13]. The performance of the solar collectors can be derived from actually taken heat $\mathrm{Q}$ with the incoming solar radiation $\mathrm{G}$.

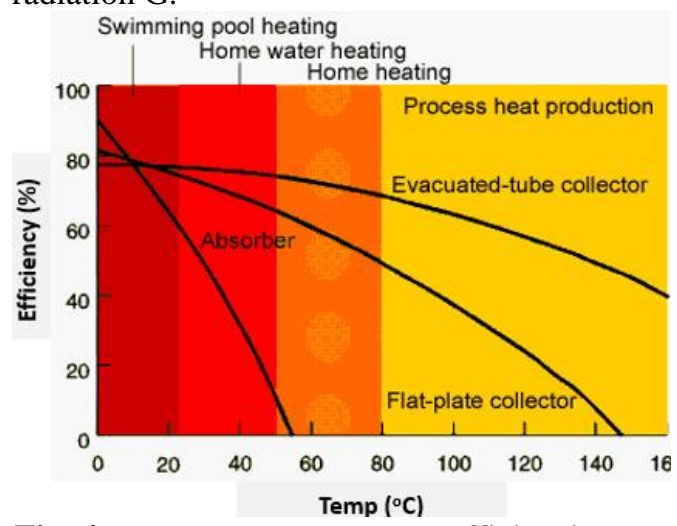

Fig. 4. Temperature Impact on efficiencies of different Solar Collectors types

So, the efficiency of the collector can be found by equation (1).

$$
\eta=\frac{Q}{G}
$$

Also Fig.5 indicates that efficiency depends upon the operating temperature of the whole system [13].

\subsection{Water heating mechanism}

The water heating mechanism is the circulation of water between the collectors and Storage tank or area where the water is used. Basically there are two types of heating water mechanism [2].

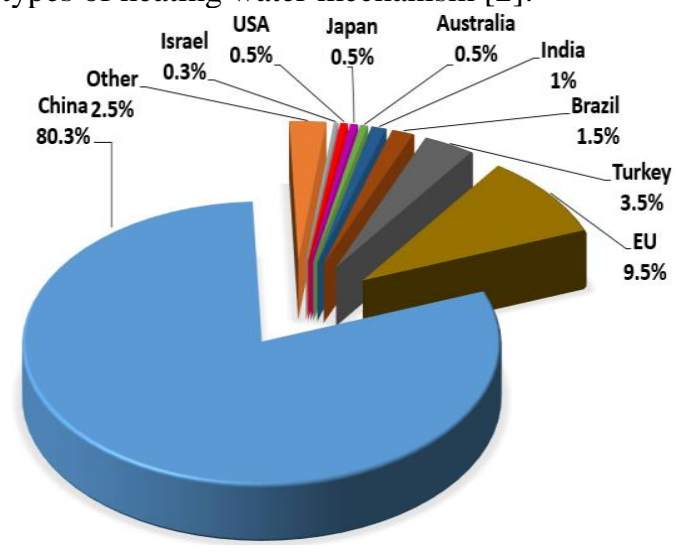

Fig. 5. Global Shares of different Countries in Solar water heaters

\subsubsection{Active system}

This method used pumps, controllers and sensors for the water flow. It can be direct flow mechanism or indirect. In direct flow mechanism as the name suggests the water flows between the collector and the storage tank without any use of the heat exchangers. They are used in the area and perform efficiently where the temperature falls rarely below the freezing.

While in indirect heating method the pump force the water to flow between the collector then heat to exchanger A nonfreezing, nontoxic (propylene glycol) heating transfer fluid is used for this processes. They are used in the area where the temperature falls below the freezing in colder climate. The active water heating system is more effective and works well 
than the passive system but due to high mechanical and controlling tools it's more expensive than the latter one. Fig. 6 shows the circulation of the water through direct and indirect active system [14, 15].

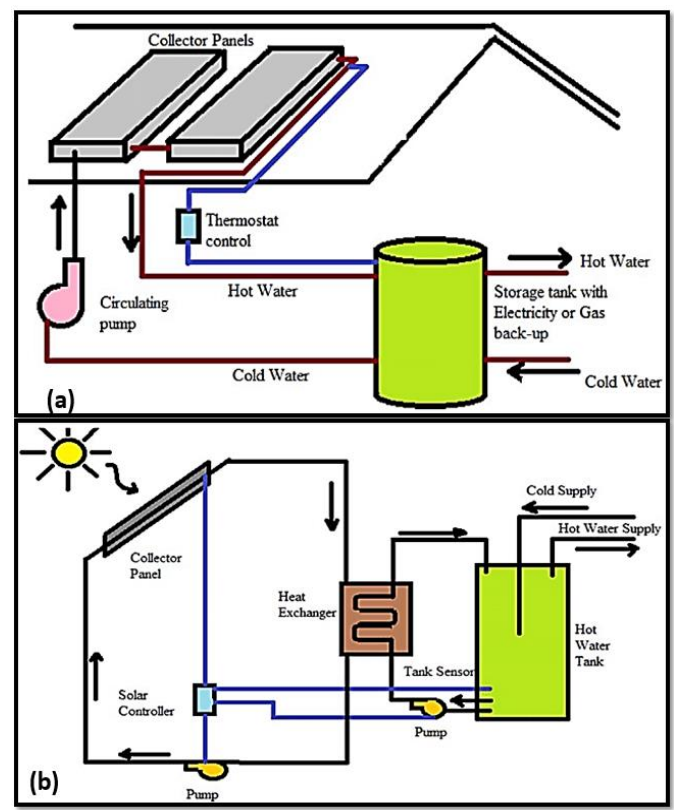

Fig. 6. (a) Direct active system (b) Indirect active system

\subsubsection{Passive system}

In This mechanism the circulation of water is through natural convection process. They are also of two types [16]

\subsubsection{Integrating collector Storage System}

It uses a tank sealed within an insulated box. These tanks are thin rectilinear shaped while the sides which have glass on its surface faces the sun. Tank act as collector and at the same time a storage as well. The water from the tank then heat up through convection process and are available for the use [17].

\subsubsection{Thermosyphon Process based Sytem}

This is also a natural process works on the simple physics principle, on the difference of the densities of the water.
When the water gets hot by the sun, it losses weight and get raises [9].

While the colder waters come to the bottoms of the collector. The risen water is then transferring to the storage taken or the header tubes which must be installed above the collector and so we don't need any tool or pumping system for the circulation of water in this system. The process of this system is shown in the Fig. 8 . These are the low temperature heater ranges from 40 to $80^{\circ} \mathrm{C}$ above ambient temperature. So they are mostly used for the domestic purposes where the average hot temperature is from 40 to $50^{\circ} \mathrm{C}$.A metallic plate absorber plate which is made of cu, steel or aluminum. Mostly it is made of copper because of tits higher conductivity as compare to the other two. It's also less corrosive [18].

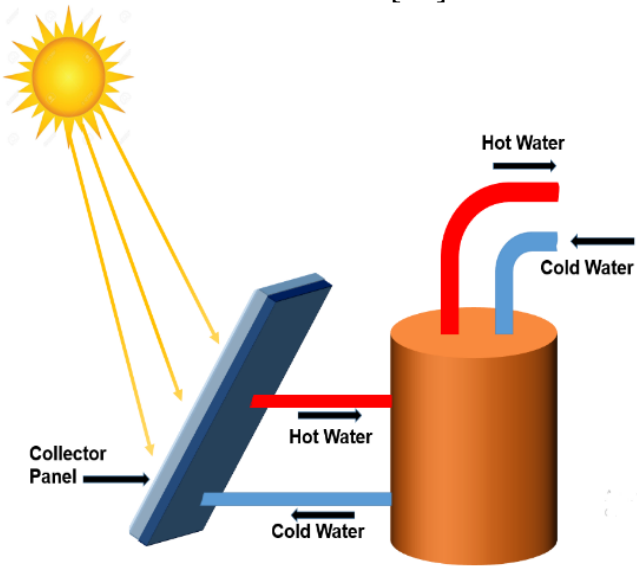

Fig. 7. Passive Solar Water Heater

\subsection{Types of Solar Collectors}

\subsubsection{Flat Plate Collectors:}

In these collectors the plate or the sheet is coated or painted black for high absorption Figure 8. Tubes are attached or the integral part of the plate which contains the HTF. The high transmittance glazing glass is used on the top of the plate. The system is enclosed in insulted box which prevent the heat loss from Collectors backs and sides. They are fixed to the frame and so doesn't need any tracking .The 
efficiency of the flat plate solar collector is around $45 \%$ [19].

\subsubsection{Evacuated Tubes Collectors}

These are latest technology based collectors and used on large scale for industrial applications where high temperature is required (up to $200^{\circ} \mathrm{C}$ ) [18] .

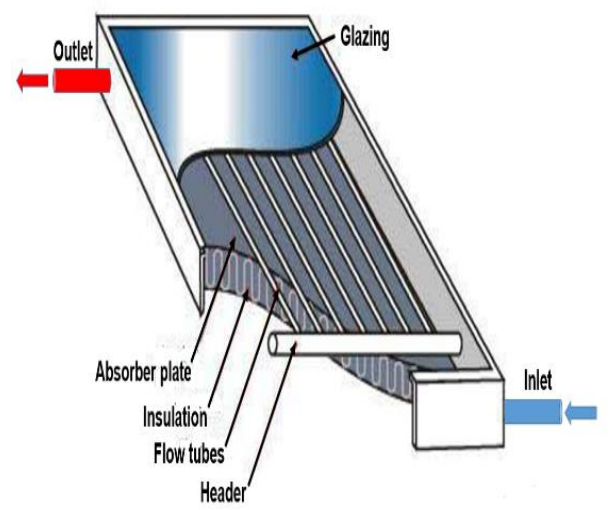

Fig. 8. Flat Plat Collector parts

The Figure 9 shows the Structure wise parts. It consists of concentric glass tubes. The inner tubes with high absorptive coating contain the tubes having HTF. The outer tube is made of borosilicate glass which maximizes the transmission of the solar radiation falling on it to the absorbing plates or tubes. With the efficiency $80 \%$, it can reaches up to 120 degree above the ambient temperature [18].Though the prices of evacuated tube collectors is high as compare to the former one. But due to some exceptional properties they are surpassing the market worldwide as shown in Figure 10 [20].

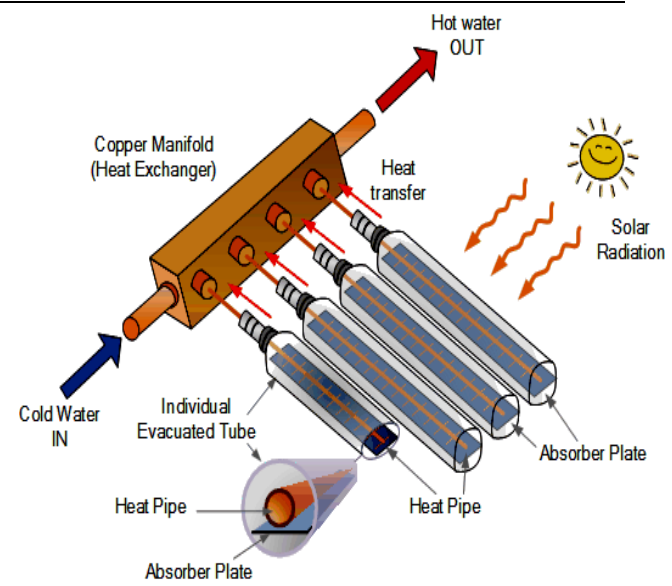

Fig. 9. Evacuated tube Collector parts

The evacuation or the removal of the air results vacuum creation between two tubes which highly reduces the heat loss through convection or conduction. Also, the curve shape permits the tubes to collects the radiations from the large angles and for long time of the day so high absorption of thermal energy occurs. Due to these parameters it retains high temperature for long time. So it could be efficient in colder regions or at nights [21].

\section{Methodology}

The Study of the paper is based on a leather industry which uses the evacuated tube collectors for heating purposes in different process. On industrial scale the hot water usage in leather and textile process is more as compared to other industries. Study says that on the average the daily requirement of hot water for a leather industry is 120,000 liter/day at a temperature of 70 to 80 degree centigrade [5]. 


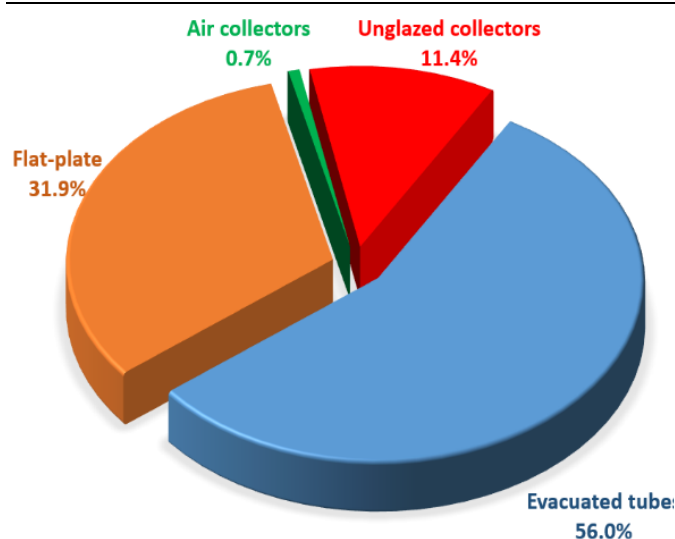

Fig. 10. Global percentage usage of Solar Collectors types

\subsection{Design Requirements}

Before going into the cost analysis. We should know about the technical and economic viability of a solar system which depend upon; how much sunshine is available throughout the year in the particular area. What would be the capital cost of the solar system?

What is the price of the conventional fuel [22].The operational and maintenance cost of the system. What is the requirement of energy annually and how much would be the temperature of the hot water is desired. Apart from these basic parameters, we also need the rate at which the conventional fuel prices escalate. Taxes and other legislative issues must also be taken into the account while designing of the plant for the area. The evolution procedure is being approach by the following method [22].

\section{a. Estimating Daily hot water load}

The daily hot water energy which could be consumed is given by:

$$
L=M C\left(T_{\text {hot }}-T_{\text {low }}\right)
$$

Where

$\mathrm{L}=$ Daily hot water energy load in $\mathrm{kWh} / \mathrm{day}$

$\mathrm{M}=$ Mass of the water in $\mathrm{kg} / \mathrm{day}$

$\mathrm{C}=$ Specific Heat of water $=0.001167$

$\mathrm{kWh} / \mathrm{kg}^{\circ} \mathrm{C}$.
$T_{\text {hot }}=$ the temperature of the hot water which is to be deliver to the load $\left({ }^{\circ} \mathrm{C}\right)$

$T_{\text {low }}$ = the temperature of the cold water which has to be given to the collector at input $\left({ }^{\circ} \mathrm{C}\right)$

Typical hot water usage on domestic scale is 40 gallons/day/person and on industrial scale a leather industry needs approximately 31700 gallons for tanning washing and bleaching of leather [4].

\section{a. Solar energy Resource}

Collector should face south in northern hemisphere. Tilt angle: latitude of the areas $\left( \pm 15^{\circ}\right.$ for winter and summer respectively).

\section{b. Solar water Heater system size}

The size of the solar water heater system can be deducted by the following formula:

$$
A_{C}=\frac{L}{n_{\text {solar }} \times I_{\max }}
$$

Where;

$A_{C}=$ area of collector in $\mathrm{m}$

$L=$ daily load in $\mathrm{kWh} /$ day

$I_{\max }=$ Maximum insolation of the region

$n_{\text {solar }}=$ efficiency of solar water heater collector

Typically, we take $=50 \%$ for evacuated tube

And $40 \%$ for flat plate [22].

\section{c. Annual Energy Saving}

The amount of energy that could be saved annually is given by the formula:

Es

$=\frac{\left(A_{c} \times I_{\text {ave }} \times n_{\text {solar }}\right) 365}{n_{\text {boiler }}}$

Where

$I_{\text {ave }}=$ Average solar radiation of the particular area $\left(\mathrm{kWh} / \mathrm{m}^{2} /\right.$ day $)$

$n_{\text {boiler }}=$ Auxiliary heater efficiency The study says gas heater efficiency is = 0.43 to 0.86 . We will assume it 0.57 . 
While the electric heater efficiency is = 0.77 to 0.97 . And we will assume it 0.88 .

\subsection{Cost of Install Solar system}

The installed system cost can be find out by the following relation [7]:

$$
C=C_{\text {solar }} \times A_{C}
$$

Where, $C$ is the total cost of the install Solar system and $C_{\text {solar }}=$ Cost of the solar per unit area $\left(\mathrm{m}^{2}\right)$ while $A_{c}$ is the solar water heater system size respectively;

\section{a. Cost saved annually}

The total cost in annual basis can be calculated by the relation given.

$$
S=E_{S} \times C_{e}
$$

\section{b. Simple back period}

The simple back period of the system can be found out by formula given below.

$$
S P B=\frac{C}{S}
$$

Where, $C$ is cost of installed the system and $S$ is the cost saved annually.

$C_{e}$ is the cost of the conventional or auxiliary energy.

\section{c. Tariff in Pakistan}

Domestic Electricity Average Unit is PKR 15/kWh. While for Industrial its Average Unit is PKR 22/ kWh.

Similarly, for gas SNGPL Current rates are Domestic: [22]

Slab $1=$ PKR 110/MMBtu for up to $1 \mathrm{Hm}^{3}$ Slab $2=$ PKR 220/ MMBtu over 1 to $3 \mathrm{Hm}^{3}$ Slab 3 = PKR 600/MMBtu above $3 \mathrm{Hm}^{3}$ While for Industrial Consumers (leather industries) its rate is PKR 600/ MMBTU. In next Section the Mathematical equations explained in above section are applied on simple mathematical approach for Industrial and Domestic consumers both.

\section{Results and Discussions}

\subsection{Cost Analysis for an Industry}

As Already mentioned leather industry almost needs 120,000 liters of hot water at 60 to $70^{\circ} \mathrm{C}$.

So the industry selected has a setup for water heating through solar water heaters and having capacity of 90,000 liter of hot water at $10^{\circ} \mathrm{C}$ rise to the incoming water. Means if water comes at inlet at $50^{\circ} \mathrm{C}$ it will gets heated up to $60^{\circ} \mathrm{C}$.Applying the steps mentioned above:

\section{a. Daily hot water load}

$L=M C\left(T_{\text {hot }}-T_{\text {low }}\right)$

Total mass of water in $\mathrm{kg}$ :

1 liter $=0.264$ gallons

Also 90,000 liter in $\mathrm{kg}=89972 \mathrm{~kg}$ (Per

day requirement of industry)

So, $\mathrm{M}=89972 \mathrm{~kg}$

$\mathrm{C}=0.001167 \mathrm{kWh} / \mathrm{kg}^{\circ} \mathrm{C}$

While as the $\Delta \mathrm{T}$ is $10^{\circ} \mathrm{C}$.

Putting the values in equation (2) we get.

$$
\begin{aligned}
& L \\
& =89972 \times 0.001167\left(10^{\circ} \mathrm{C}\right) \\
& L=1050 \mathrm{kWh} / \text { day. }
\end{aligned}
$$

$$
A_{C}={ }_{L}^{\text {b. }} \text { System size }
$$

Putting the values in equation we get,

$n_{\text {solar }}=0.50$ and $I_{\max }=5.5 \mathrm{KWh} / \mathrm{m}^{2}$ for the region where the industry is located.

$$
A_{C}=\frac{1050}{0.50 \times 5.5}
$$

$A c=381 \mathrm{~m}^{2}$

\section{c. Annual Energy saving}

$$
=\frac{\left(A_{c} \times I_{\text {ave }} \times n_{\text {solar }}\right) 365}{n_{\text {boiler }}}
$$


Aitezaz (et al.), Techno-Economic Analysis of Solar Thermal Water Heaters in Pakistan

(pp. $36-46)$

For gas heater we usually take the $n_{\text {boiler }}=$ 0.57

To know about how much Energy has been saved per year, putting the corresponding values in equation (4), we get;

Es

$$
=\frac{(381 \times 5.25 \times 0.50) 365}{0.57}
$$

$E s=640430 \mathrm{kWh} /$ year, which is equal to 2,185.237866 MMBTU/year * $1 \mathrm{kWh}=$ 0.00341 MMBTU.

d. Cost of install solar system:

$$
C=C_{\text {solar }} \times A_{C}
$$

Where Csolar is the collector cost per unit area. In Pakistan for the cost ranges from 25000 to 40000 rupees. We would consider an average rate of PKR 32000/=

$$
C=32000 \times 381
$$

\section{$C=$ PKR $12192000 /-$}

\section{e. Annual Cost saving:}

If we are using the gas as our auxiliary heater source. Then to find out how much cost has been saved we have the following equation:

$$
S=E_{S} \times C_{e}
$$

At present as already mentioned above that Pakistan commercial rates are 600/MMBTU [22]. Putting the values in equation (6)

$$
S=2185.86 \times 600
$$

\section{$S=$ PKR 1300000/ year approximately.}

But as the gas is not sufficient enough to meet the demand of the country and there is obvious cut off of gas in winters. So the industries mostly relay on Bio Fuel Like wood and Crops residues as there conventional sources of heat producing which cost approximately RS 2200/- to produces 1 ton of steam [23].

\section{f. Simple payback period:}

$$
S P B=\frac{C}{S}
$$

$S P B \approx 9$ Years.

\subsection{Cost analysis for a House}

To ensure safety on domestic scale, the solar water heaters must be used under the pressure relief value to supply and control the suitable temperature The mixing or sometimes the tempering vales must be used if there is any possibility of the temperature reaching to highest point the Figure 11 shows the typical two tank solar water heater collection in homes having the acceptable vales and pipe connections [18]. The Study says that the average use of hot water for one adult person per day is $40 \mathrm{gal} /$ day [22]. Hence for 4 family members' at least 160 gal/day would be required.

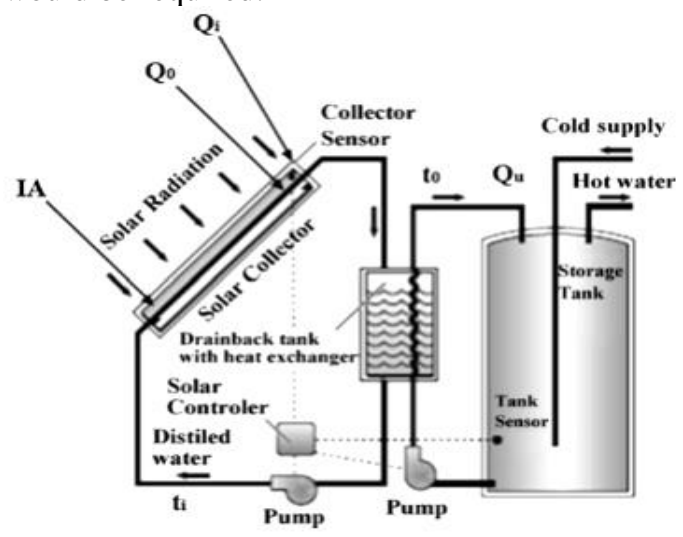

Fig. 11. Figure 11: Flow of water in domestic solar Water heating system.

Gas water heater can have storage for a time being or it could be used for instantaneous delivery. Load of water in $\mathrm{kg} /$ day would 160 gallons of water $=606 \mathrm{~kg} /$ day.

Let the inlet is $18^{\circ} \mathrm{C}$ and the outlet we need $50^{\circ} \mathrm{C}$.so applying the steps

As from equation (1);

$\mathrm{L}=606 \times 0.001167\left(50^{\circ} \mathrm{C}-18^{\circ} \mathrm{C}\right)$

$\mathrm{L}=22.6 \mathrm{kWh} /$ day

Now as $1 \mathrm{kWh}=0.00341 \mathrm{MMBTU}$

So in MMBTU the total load would be $=$ 0.077 MMBTU

From Equation (3);

Ac $=(22.6 \div 0.50) \times 5.5$

$\mathrm{Ac}=8.2 \mathrm{~m}^{2}$ 
From Equation 4:

Es $=(8.2 \times 5.25 \times 0.50 \times 365) \div 0.57$

Es $=13783.55 \mathrm{kWh} /$ year and in MMBTU

it would be $=47$ units $: 1 \mathrm{kWh}=0.00341$

MMBtu

As already mention that the domestic slabs

from SNGPL the average MMBtu is around PKR 310/-

The total cost saving on yearly basis would be PKR 14570/-

For 4 family members on domestic scale single unit of the 300-liter capacity is enough. That is easily available in market from 30,000 to 60,000 depending on the quality and type and the average cost of single evacuated tube collector could be 40,000/300lit. Taking the labor and other tooling cost (storage tank pipes etc.) cost may reach to 50,000 [8].

So, for the final cost simple payback period would be:

$S=50,000 \div 14570 \approx 3.5$ years.

\section{Conclusion}

Two commercially available solar thermal heaters have been investigated, analyzed and compare with the conventional water heating system. From above discussion we can conclude that Evacuated tubes heaters are more efficient due to its thermal insulated glass. Solar thermal water heater of the lather industry has been mathematically investigated and compared with that of its conventional gas heaters, wherein 2185 units per year MMBTU have been saved. Moreover, for average house of four members is also examined wherein solar thermal system saved 47 units per year MMBTU. Additionally, solar thermal water heaters optimally contribute to our ecosystem by significantly reducing carbon footprint compared to conventional water heaters. On industrial scale the solar thermal water heating system has more viability in the sense of economics for larger use of collectors.

Solar thermal water heaters have very huge potential in the northern areas of
Pakistan and hot regions of Baluchistan where there is very little or no gas and also have relatively high insolation up to average of $8 \mathrm{kWh} / \mathrm{day} / \mathrm{m}^{2}$. Moreover, industries where water is heated by conventional heating system can contribute in the energy saving by incorporating solar thermal heating system and consequently reduce the burden of energy shortage in country like Pakistan.

\section{REFERENCE}

[1] M. H. Baloch, G. S. Kaloi, and Z. A. Memon, "Current scenario of the wind energy in Pakistan challenges and future perspectives: A case study," Energy Reports, vol. 2, pp. 201-210, 2016.

[2] T. Aized, M. Shahid, A. A. Bhatti, M. Saleem, and G. Anandarajah, "Energy security and renewable energy policy analysis of Pakistan," Renewable and Sustainable Energy Reviews, vol. 84, pp. 155-169, 2018.

[3] M. H. Baloch, J. Wang, G. S. Kaloi, A. A. Memon, A. S. Larik, and P. Sharma, "Techno-economic analysis of power generation from a potential wind corridor of pakistan: An overview," Environmental Progress \& Sustainable Energy, vol. 38, no. 2, pp. 706-720, 2019.

[4] M. H. Baloch et al., "Hybrid energy sources status of Pakistan: An optimal technical proposal to solve the power crises issues," Energy Strategy Reviews, vol. 24, pp. 132-153, 2019.

[5] I. Ullah, M. G. Rasul, A. Sohail, M. Islam, and M. Ibrar, "Feasibility of a Solar Thermal Power Plant in Pakistan," in Thermal Power PlantsAdvanced Applications: IntechOpen, 2013.

[6] R. P. Butt, I. A. Chaudhry, I. Zahid, and M. A. Shakir, "ENHANCEMENT OF WIND POWER GENERATION IN PAKISTAN," Science International, vol. 27, no. 6, 2015. 
[7] M. Hussain Baloch, D. Ishak, S. Tahir Chaudary, B. Ali, A. Asghar Memon, and T. Ahmed Jumani, "Wind Power Integration: An Experimental Investigation for Powering Local Communities," Energies, vol. 12, no. 4, p. 621, 2019.

[8] B. Memon, M. H. Baloch, A. H. Memon, S. H. Qazi, R. Haider, and D. Ishak, "Assessment of Wind Power Potential Based on Raleigh Distribution Model: An Experimental Investigation for Coastal Zone," Engineering, Technology \& Applied Science Research, vol. 9, no. 1, pp. 3721-3725, 2019.

[9] F. Muhammad, M. W. Raza, S. Khan, and F. Khan, "Different solar potential co-ordinates of Pakistan," Innovative Energy \& Research, vol. 6, no. 2, 2017.

[10]P. John, "Solar Evolution-The History of Solar Energy," ed: California: California Solar Center, 2002.

[11] J. L. Sawin et al., "Renewables 2010Global status report," 2010.

[12] A. Gastli and Y. Charabi, "Solar water heating initiative in Oman energy saving and carbon credits," Renewable and Sustainable Energy Reviews, vol. 15, no. 4, pp. 1851-1856, 2011.

[13] J. A. Duffie and W. A. Beckman, Solar engineering of thermal processes. John Wiley \& Sons, 2013.

[14] A. Shafieian, M. Khiadani, and A. Nosrati, "Strategies to improve the thermal performance of heat pipe solar collectors in solar systems: A review," Energy conversion and management, vol. 183, pp. 307-331, 2019.

[15] M. Hanoin, N. Mohammed, M. Arris, A. Bakar, N. Mokhtar, and A. Razak, "Fabrication and Performance Evaluation of Integrated Solar-Driven
Membrane Distillation System with Serpentine-shape of Flat Plate Solar Collector for Seawater Desalination," Journal of Applied Membrane Science \& Technology, vol. 23, no. 3, 2019.

[16] S. A. Kalogirou, "Chapter 5. Solar Water Heating Systems," Solar Energy Engineering, second ed., Academic Press, Boston, p. 257, 2014.

[17]G. Sootha, "Solar Thermal Applications," in Physics and Technology of Solar Energy: Springer, 1987, pp. 467-473.

[18] M. Hossain et al., "Review on solar water heater collector and thermal energy performance of circulating pipe," Renewable and sustainable energy reviews, vol. 15 , no. 8, pp. 3801-3812, 2011.

[19] N. Benz, M. Gut, and T. Beikircher, "Solar process heat with nonconcentrating collectors for food industry," in Proceedings of ISES Solar World Congress, 1999.

[20] S. H. Worldwide, "Solar Heating and Cooling Programme," International Energy Agency, 2016.

[21]G. S. Chandraprabu Venkatachalam, "Evacuated Tube Solar Collectors: A Review," (in English), International Journal of Scientific Engineering and Research (IJSER), Review vol. Volume 6, no. 12, December 2018, p. 4, 2018.

[22] R. Taylor, "Solar thermal technology and applications," in National Renewable Energy Laboratory, briefing slides for NAEMI Solar Electric and Thermal Training Workshop, 2006, pp. 27-29.

[23] "Saddiq Leather Works " https://www.siddiqleather.com/ (accessed.) 